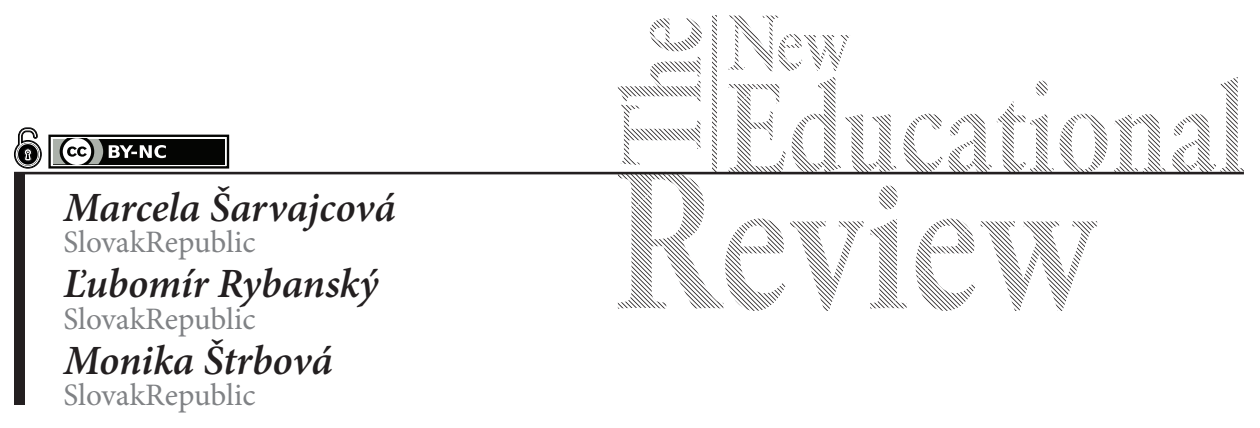

\title{
Assessing Slovak Teachers' Literacy and Related Non-cognitive Skills in the International Measurements PIAAC
}

DOI: 10.15804/tner.2021.66.4.11

\begin{abstract}
The study presents the results of PIAAC measurements and focuses on teachers as mediators of education and their achievements in literacy and skills in reading and writing at home and at work. Multiple regression analysis is used in the research to examine the influence of independent variables - earnings, age, gender and reading index - on the level of teachers' literacy. Values of the coefficient of determination vary from 0.05 (Poland) to 0.23 (Belgium). The results are compared at the country level and show the position of Slovak teachers in these measurements. Also, they highlight the most successful countries and point to the countries with positions similar to Slovakia. Based on the research findings, it can be stated that the higher level of literacy is associated with a higher level of writing and reading activities at work more than at home. An important finding is also the result that in all countries, the literacy level declines with age.
\end{abstract}

Key words: literacy, PIAAC, reading, teachers, regression analysis

\section{Introduction}

Reducing inequalities in learning outcomes is one of the major challenges of European policies. Fulfilment of this strategic goal is monitored by various international programmes such as PISA, PIRLS or PIAAC. The results of comparisons 
in the programme PIAAC focusing on teachers, have become the basis of the presented study, because teachers can be considered one of the important elements in today's knowledge economy. The teacher-student relationship is the most basic relationship in the process of education, and also a special kind of interpersonal and social relations, which is the key to students' academic, social and emotional development (Li-Xu \& Qi Yang, 2019). Education and investment in education increase participation in the labour market and that is why it is appropriate to analyze and compare results at the country level, look for differences in school systems or systems providing possibilities and opportunities for teachers in the given countries or regions.

Based on the current social and information situation, our study focuses especially on the reading literacy and reading-related skills. According to Yamin (2018), when teaching students it is important that teachers read. Reading is the main factor activating their knowledge. The reality today is that education and training systems worldwide are, to a greater or lesser extent, marked by inequalities - in access to quality education as well as in outcomes, assessment or the socio-economic inequality itself (Meroni et al., 2015, p. 314). The quality of teachers matters, since it is one of the most important school factors influencing students' achievements, while also public investment in this sphere is indispensable. Although the teacher quality cannot be characterized precisely (Hanushek \& Rivkin, 2006), teacher skills are closely associated with the productivity of education (Metzler \& Woessmann, 2012). Hanushek et al. (2014) also point to teachers' cognitive skills that are important factors explaining international differences in student performance.

\section{Research Problem}

The primary goal of this study is to analyze and determine dependencies between the level of teachers' literacy, their reading and writing behaviours at home and at work and other indicators (gender, age, income). To fulfil the goal, the following 3 research objectives were defined:

1) Comparison of teacher literacy in international measurements

2) Comparison of literacy in occupations classified as professional

3) Evaluation of use of teachers' reading skills

\section{Research Focus}

There is a number of studies dealing with analyses of PIAAC or PISA outcomes and their relationships, such as the one conducted by Meroni et al. (2015) who explain how much of the variation in student performance can be explained by teacher quality at the country level across OECD countries. The teacher quality has 
been reviewed for a long time, and teachers have often been paid also based on these reviews, e. g. obtained education or years of experience. It is also well-known that teachers' obtained education not always has an influence on students' achievements (Rice, 2003; Goldhaber \& Brewer, 2000). The presented research compares literacy of Slovak teachers with literacy of teachers in other countries, as well as Slovak teachers with other occupations in Slovakia. It is focused on teachers' skills related to literacy according to the PIAAC assessment tool (in particular writing at home, writing at work, reading at home, and reading at work), and compares them among countries while focusing also on the skills-literacy relationship. Last but not least, it analyzes Slovak teachers and compares their performances by gender, age and earnings.

\section{Methodology of research}

PIAAC is one of the international assessment studies using standardized performance tests to measure cognitive skills in adults from 16 to 65 years of age, while assessing also the use of the skills in personal and professional life. The study involves more than 150 thousand adults from 24 countries of the world. PIAAC examines three cognitive skills - literacy, numeracy and problem solving in technology-rich environments (PSTRE). The PIAAC survey data are accessible to the public, but their analysis is considerably limited by available analytical tools allowing taking into account the complex design of the study. The unbiased estimate of persons' skills across the population uses the approach based on plausible values combining techniques of the item response theory (IRT) and latent regression (Caro \& Biecek, 2017). The proficiency achieved by respondents in each of the three domains is measured on a 0 to 500 -point scale with the standard deviation of 100 points, and the continuous scores can be converted to the level of skills (from less than 1 to 5 for literacy and numeracy and from less than 1 to 4 for PSTRE) (Feinberg et al., 2019). Ten plausible values and 80 individual replicate weights are used for the PIAAC scores in each skill.

In 2004, OECD came with the initiative to create a module on requirements of generic work skills for direct assessment of skills (literacy, numeracy, PSTRE). The module was named Job Requirements Approach (JRA). In JRA, working respondents were asked to indicate the level of skills required for performance of their current work, in several skill domains. The basic idea was that working respondents report qualification requirements of their occupation (OECD, 2016). Overall, 12 scales (indices) were constructed, of non-cognitive skills used at work 
and outside of work, out of which four relate to literacy (two scales of reading behaviour: READHOME, READWORK, and two scales of writing behaviour: WRITHOME, WRITWORK). Each of these skills is measured on a scale where the median is 2 and the standard error of estimate is 1 . Values of the indices for respondents are estimated using the IRT method, in particular the generalized partial credit model (GPCM). Its estimates are based on respondents' answers using 5-point Likert scle.This scale reflects the way they perform the activities writing behaviour: writing letters/memos/emails, writing articles for newspapers/ magazines, writing reports, filling in forms; and for reading behaviour and reading behaviour: reading directions or instructions, reading articles in newspapers/ magazines/information bulletins, reading articles in journals/publications, reading books/fiction/non-fiction, reading manuals/reference materials, reading bills/ invoices/ bank statements/ financial reports, reading diagrams/ maps/ schematics (von Davier et al. 2016).

\section{Sample of Research}

For the purpose of the study, we have decided to use mostly respondents' occupations according to the classification ISCO2008 where all those under the ISCO code 23 are defined as teaching professionals. They include the range of teachers from elementary schools to universities. The two-digit code beginning with the digit 2 includes professionals, in particular: 21 - Science and Engineering Professionals (SEP), 22 - Health Professionals (HP), 23 - Teaching Professionals, 24 - Business and Administration Professionals (BAP), 25 Information and Communications Professionals (ICP), 26 - Legal, Social and Cultural Professionals (LSCP).For many countries, the three-digit or four-digit ISCO classification that would allow distinguishing among elementary school, secondary school and higher education institution or university teachers is not available.

Sizes of research samples of the countries the study works with below, consist of countries participating in the first round of the survey carried out in $2011-2012$ (OECD, 2013) whose ISCO2 classification is available in PIAAC, i. e. the following countries: Belgium, Czech Republic, Denmark, France, Germany, Ireland, Italy, Japan, Korea, Netherlands, Norway, Poland, Russian Federation, Slovak Republic,Spain, Sweden, United Kingdom (England), USA. Participation of teachers ranges from 3.0\% $(\mathrm{N}=185)$ in Japan to $7.3 \%(\mathrm{~N}=643)$ in Denmark $7.4 \%(\mathrm{~N}=643)$ (Meroni et al., 2015).

Statistical calculations were conducted with the program R (R Core Team, 2018), the package intsvy (Caro \& Biecek, 2017). 


\section{Results of Research}

The first important information regarding the focus of the study is the comparison of teachers' level of literacy on an international scale. In the ranking of 18 countries of the world, Japan holds the highest position $(\mathrm{M}=317.8$; $\mathrm{SD}=32.3)$, followed by the Netherlands $(\mathrm{M}=307.7 ; \mathrm{SD}=36.9)$ and Norway $(\mathrm{M}=302.5 ; \mathrm{SD}$ =36.4). Slovakia is down to $16^{\text {th }}$ position $(\mathrm{M}=286.8 ; \mathrm{SD}=32.3)$, followed only by the Russian Federation $(M=280.4 ; S D=39.7)$ and Italy $(M=275.4 ; S D=40.1)$.

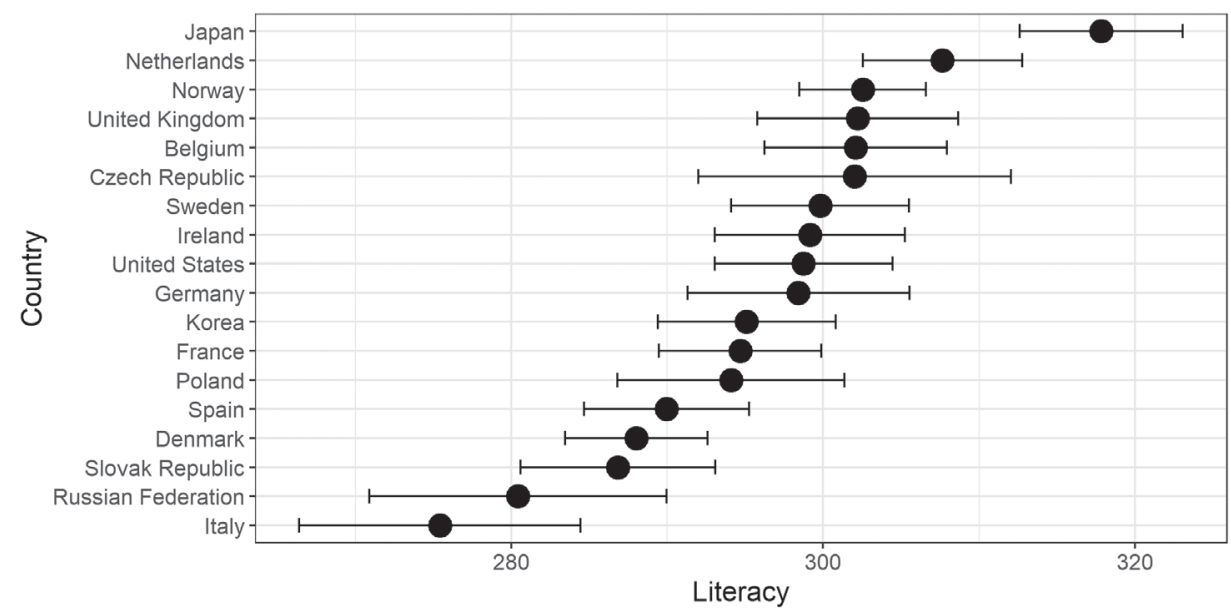

Figure 1. Graphic summary of mean scores and standard errors of estimates in teachers' literacy across countries Source: Authors, 2020

\section{Literacy in occupations classified as Professional}

From among six categories of professionals, teachers do not achieve the highest level even in one country. The best, this in the third position, are teachers in the CzechRepublic, Ireland, Japan, France and Sweden.

Comparison of earnings, this monthly salaries excluding bonuses (EARNMTH) in professional occupations, shows that teachers have the lowest earnings even in eight countries (Czech Republic, Denmark, Italy, Norway, Poland, Russian Federation, Slovak Republic, United Kingdom), and the best earnings, specifically the third place, in Japan. Spearman's correlation coefficient between the mean level of literacy and the mean level of earnings for professional occupations has a negative value in the Slovak Republic $\left(\mathrm{r}_{\mathrm{S}}=-.02, \mathrm{p}=.872\right)$ and Spain $\left(\mathrm{r}_{\mathrm{S}}=-.08, \mathrm{p}=.957\right)$, 


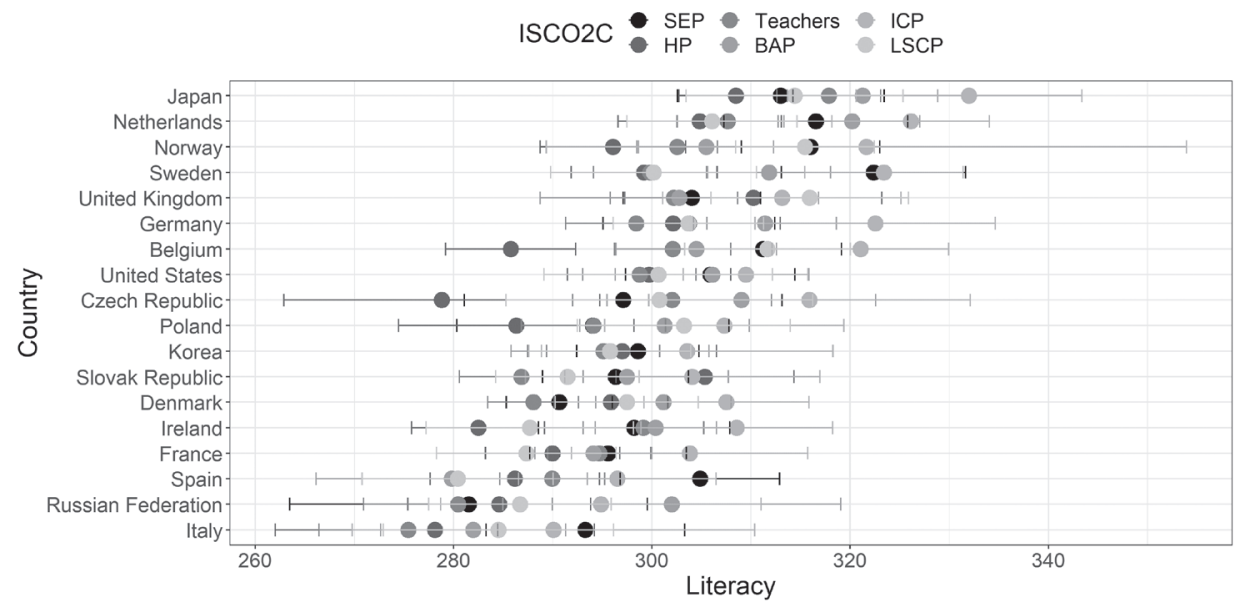

Figure 2. Graphic summary of mean scores and standard errors of estimates in literacy of professionals (according to ISCO) in various countries

Source: Authors, 2020

but its value is positive in the other countries, this beginning with Italy $\left(\mathrm{r}_{\mathrm{S}}=.02\right.$, $\mathrm{p}=.953)$, United Kingdom $\left(\mathrm{r}_{\mathrm{S}}=.14, \mathrm{p}=.787\right)$ up to Denmark $\left(\mathrm{r}_{\mathrm{S}}=.82, \mathrm{p}=.040\right)$ and the Netherlands $\left(\mathrm{r}_{\mathrm{s}}=.88, \mathrm{p}=.018\right)$.

\section{Assessment of the use of teachers' readingskills}

In terms of the level of reading and writing skills required by the teaching profession in the participating countries, USA take the first place in all four domains, and Germany the second in three domains (writing at home, reading at work and reading at home). The last place in all four domains is taken by the Russian Federation. Japanese teachers with their use of reading and writing skills are in the bottom third of the ranking $\left(16^{\text {th }}\right.$ place and $14^{\text {th }}$ place), and at the top of the ranking (3rd place) only in writing at work. Slovak teachers, on the contrary, are in the fourth position in reading at home. In writing and reading at work, they place in the bottom part of the ranking ( $15^{\text {th }}$ and $17^{\text {th }}$ place).

\section{Multiple regression analysis}

Multiple regression analysis has been used to examine the influence of independent variables, this specifically teachers' earnings (EARNMTH), the use of reading and writing skills (READWORK, WRITWORK, READHOME, WRITHOME) at home and at work, age and gender. Since PIAAC survey does not use 


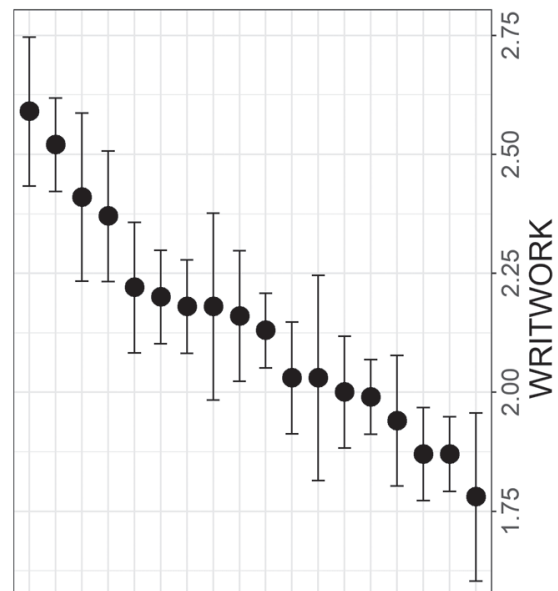

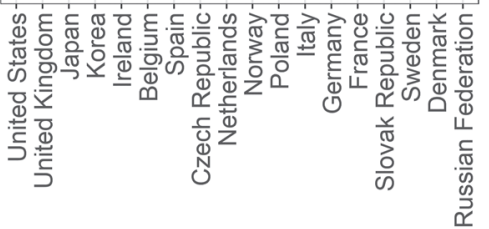

Kulunoว

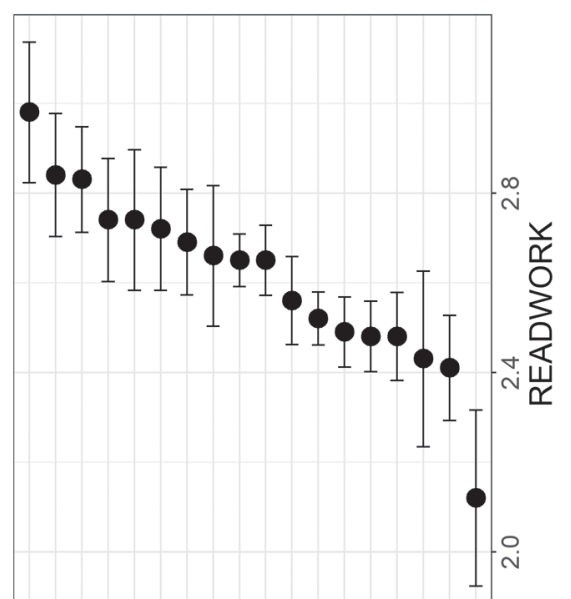

कि

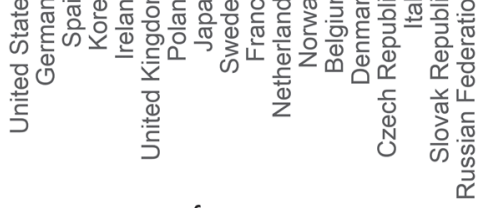

Kมฺนnoว

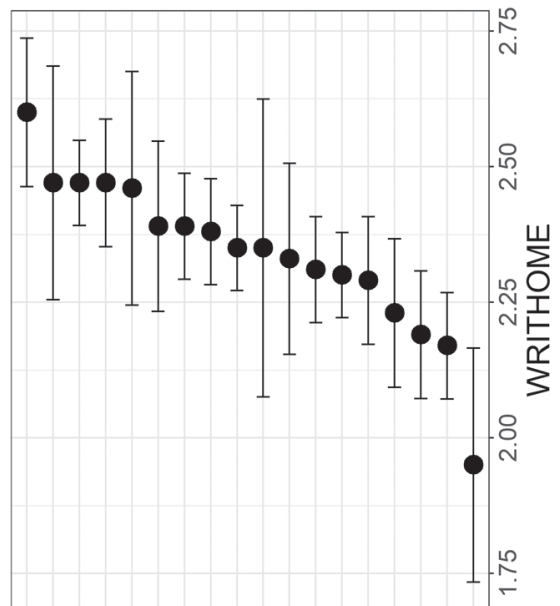

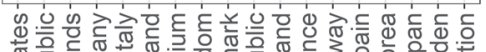

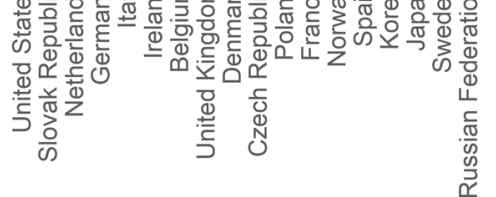

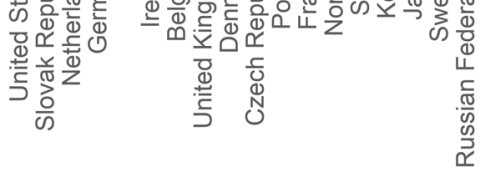

Kıฺunoว
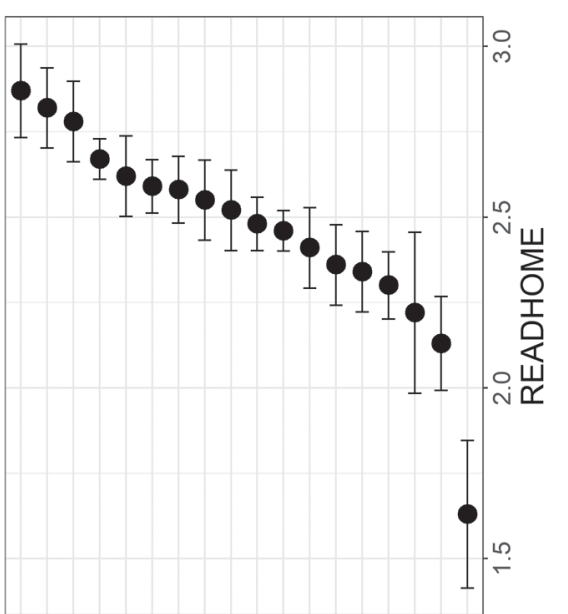

की

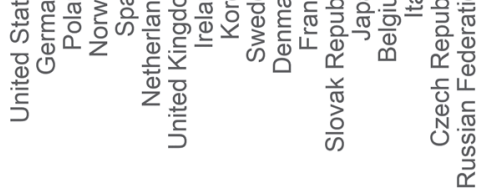

Kupunos 

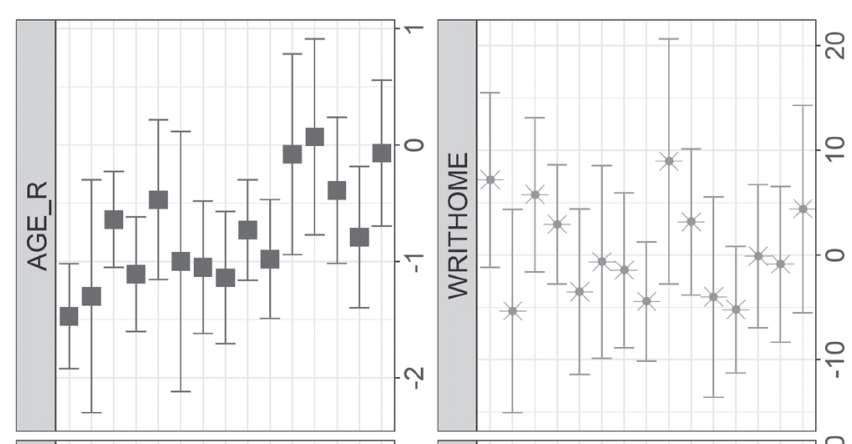

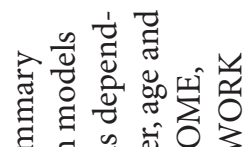

营

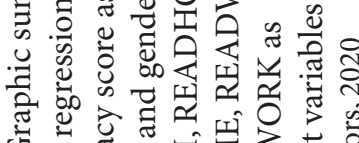

பँ

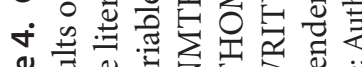

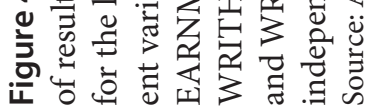
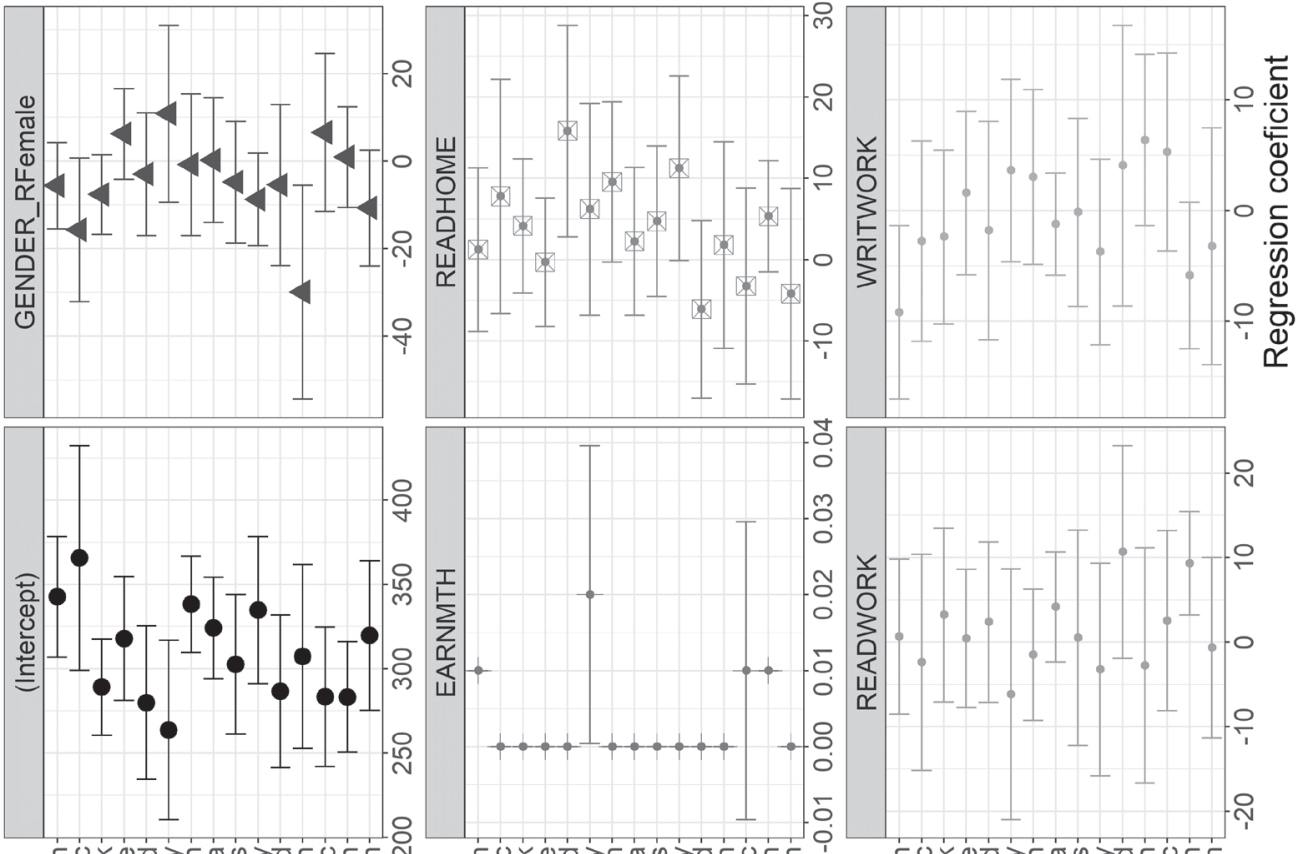

E.․ㅡㄴ

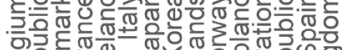

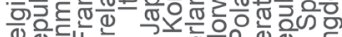
ه

过
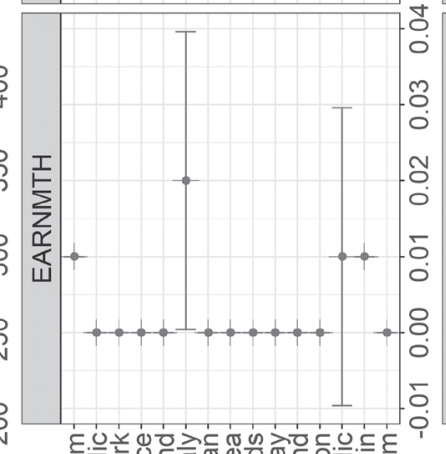

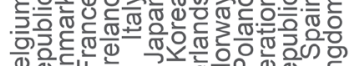

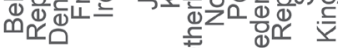

足

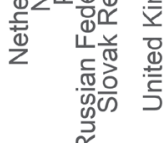
Kununoว



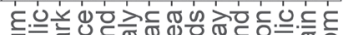
弱

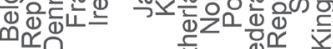
过

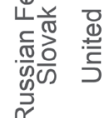

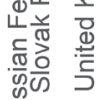
$\vec{x}$ 
the same replication schemes for all countries, it is not possible to construct one regression model for the whole dataset. A regression model is estimated for each country (except for USA, Sweden and Germany for which there are no data about earnings in the PIAAC dataset). For the sake of clarity of the result presentation, the estimated regression coefficients and their standard errors are depicted graphically in Figure 3. It is true especially for Slovak teachers that none of the considered independent variables is statistically significant: gender $(\beta=6.52, p=$ $.478)$, age $(\beta=-0.39, \mathrm{p}=.222)$, EARNMTH $(\beta=0.01, \mathrm{p}=.352)$, READHOME $(\beta$ $=-3.26, \mathrm{p}=.596)$, WRITHOME $(\beta=-0.12, \mathrm{p}=.976)$, READWORK $(\beta=2.53, \mathrm{p}=$ $.638)$, WRITWORK $(\beta=5.28, \mathrm{p}=.246)$.

Regression coefficients of the variable age are negative for all countries except for the Russian Federation, while statistically significant in nine of them (Belgium, Czech Republic, Denmark, Spain, France, Japan, Korea, Netherlands and Norway). Literacy scores in terms of gender are statistically significant $(\beta=-29.96, p=.016)$ only in the Russian Federation. In five countries (Slovak Republic, Spain, France, Italy and Korea), female teachers achieve higher literacy scores than male teachers. Regression coefficients of earnings (EARNMTH) are positive for all countries except for Norway $(\beta=-0.01, p=.865)$, but statistically significant only for Spain, Italy, Korea and the Netherlands. Indices of reading at work - READWORK are positive for most countries (Belgium, Denmark, France, Ireland, Korea, Netherlands, Poland, Slovak Republic), but statistically significant only for Spain ( $\beta=$ $9.32, \mathrm{p}=.001)$. Indices of reading at home - READHOME are negative only in three countries (United Kingdom, Poland and Slovak Republic), statistically significant only for Ireland $(\beta=-15.81, p=.017)$. Regression coefficients for indices of writing at work - WRITWORK are positive in five countries (France, Italy, Japan, Poland, Slovak Republic), but statistically significant only for Belgium $(\beta=-9.21, p$ $=.021)$. Regression coefficients for indices of writing at home - WRITHOME are positive in six countries (Belgium, Denmark, France, Norway, Netherlands, United Kingdom), but not statistically significant in any of them.

Figure 4 gives account of Slovak teachers. When reading at home - READHOME, Slovak teachers most frequently read letters, memos, emails (51.4\%), and newspapers and magazines (51.4\%). Letters, memos, emails (47.4\%) stand out on a daily basis also when reading at work - READWORK. At least once a week, their reading at work includes journals and publications (40.6\%). Generally speaking, Slovak teachers read more than they write.It is interesting that they do not write articles either at work or at home - articles (WRITHOME 0\%, WRITWORK 1.1\%). Most of them write letters, memos and emails daily (WRITHOME 40.6\%,WRITWORK44.6\%). 


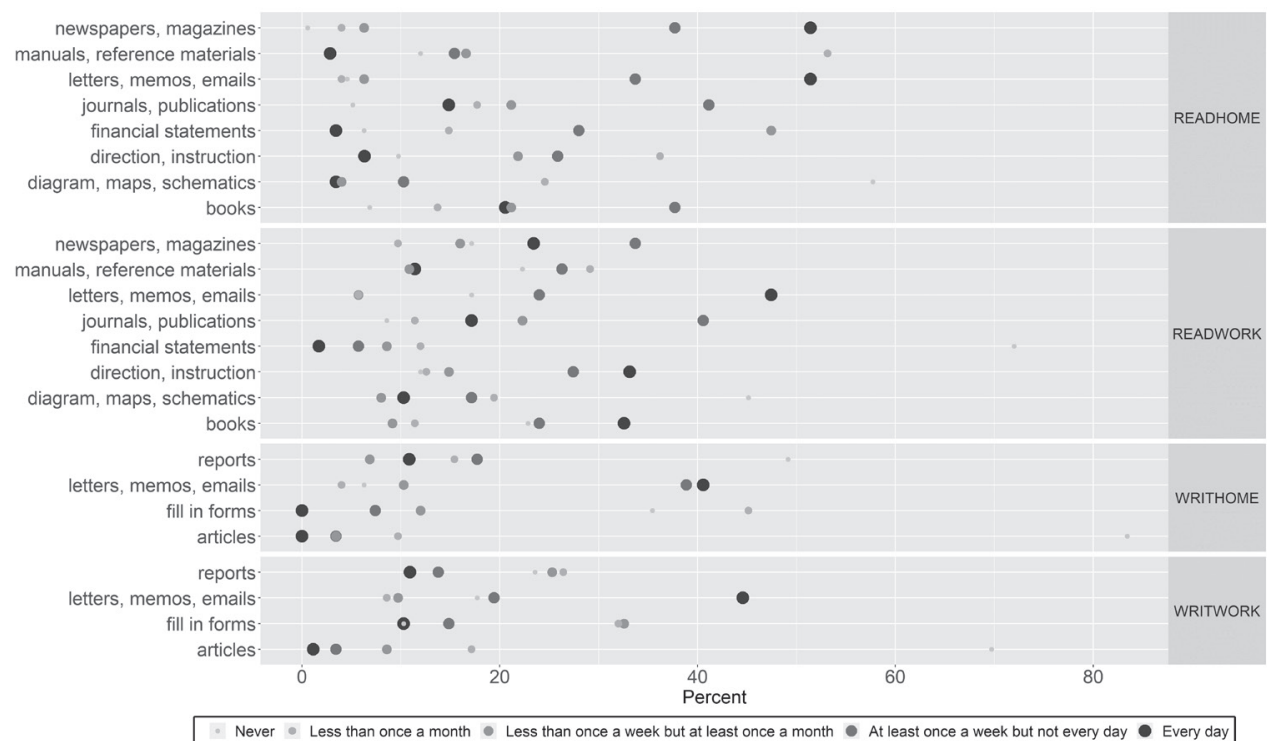

Figure 5. Intensity of specific reading and writing activities of Slovak teachers at work and at home

Source: Authors, 2020

\section{Discussion}

The starting point of this research is Slovak teachers ranking in literacy as low as $16^{\text {th }}$ among 18 countries and the comparison of Slovak teachers' non-cognitive skills within the reading skill, where they do not excel in any of the skills. Reasons for the bad position in the international comparisons can be seen in various areas. The research concentrates on one of the key factors influencing the performance, which is the salary. The expected result is that teachers with a higher level of literacy have higher earnings (it is true in all countries except for France and Ireland). However, there is an unanswered question worth further research, whether it is not exactly the earnings that move „smart" teachers (thus those with a higher literacy level) to other occupations, since underfunding education is a long-term problem for Slovakia.

It is evident from the research by Uhrínová and Tirpák (2020, p. 56) that the growing problem of European education systems is the shortage of teachers, especially in some subjects and in certain regions. In some countries, the aging 
teacher population and the perception of the overall low prestige of the teaching profession may increase the pressure on education systems. The decline itself of the prestige of the teaching profession may be caused by increasing bureaucracy, not only in Slovakia, which is associated with performance of this profession, or relatively low salaries in comparison with salaries in other intellectual professions. Ibrahim\& Zaatari (2019) in their case study also assume that nowadays, schools are increasingly driven by achievement and standardized assessments. The whole educational experience becomes mechanized, and the nurturing and social dimensions become unimportant.

The comparison of teachers with other professions from among six professions categorized as "professionals” (according to ISCOIC) is also interesting. Teachers are in the last place in the level of literacy, this not only in Slovakia; the picture of Slovakia, however, is complemented by the fact that Slovak teachers have the lowest salaries of the given professions.

There are some research reports analyzing and comparing results of PIAAC and PISA measurements, thus looking for dependencies of the relationship between the quality of the teacher (or his/her results) and the quality of students (or their results) (Lundetrae at al., 2014; Cortina, 2015). The teacher - child relationships influence child development to such an extent that not only a child's academic performance, but liking of school as such, work habits, social skills and behaviour depend on this relationship. This relationship cannot be a business relationship (trading one thing for another) but must be pedagogical (Abun \& Magallanes, 2018).

\section{Conclusion}

This study focuses on the comparison of the level of literacy and related non-cognitive skills at the country level, with the focus on Slovakia having long lagged behind in international measurements. Using several statistical analyses, the study presents Slovak teachers' positions in comparison with other professionals. An interesting finding is that in Slovakia, female teachers' literacy is higher than male teachers' literacy (288 vs. 284) (in most countries, the higher literacy level is achieved by men). An important indicator, analyzed especially because of the social situation in Slovakia, appears to be the teacher salary which is one of the key problems in the education system. Teachers with a higher level of literacy have higher earnings. This model applies to all countries except for France and Ireland. Teachers have the lowest salaries among the selected professions not only in 
Slovakia but also in other seven countries. Such results allow for further research focused on the influence of the salary amount and teacher quality.

The result that can be considered a good predisposition for further research is the finding that Slovak teachers have a high level of reading at home; on the contrary, they are in the bottom part of the ranking in writing and reading at work. Thus, the question for further research is why it is the skill at home that Slovak teachers are better at when compared with other aspects of literacy. So far it can be assumed that schools, as all institutions in this country, have many administrative duties, which teachers perform at home.

The fact that teachers' reading and writing behaviours are self-reported only, thus some items may not be objective, may be considered to be the limitation of this research. Furthermore, the latest gathered data are from 2017 therefore it would be ideal to carry out the same research in near future and follow up the development of teachers' reading and writing skills over time.

Teachers' literacy is a very crucial thing in education and the education system, and it needs to be paid constant attention aiming at pointing out to shortcomings in weaker countries and looking for inspirations in countries that excel.

This work was supported by the Agency for Research and Development under the Agreement No. APVV-17-0071 and the Scientific Grant Agency of the Ministry of Education, Science, research and Sports of the Slovak Republic under the agreement No. VEGA $1 / 0062 / 19$.

\section{References}

Abun, D. \& Magallanes, T. (2018). Choosing Proper Relationship between Teacher and Students. Retrieved 5/07/2020, from https://www.researchgate.net/search.Search.htm1 ?type $=$ publication\&query=teacher\% 20 and $\% 20^{\text {st }}$ udent

Caro, D.H., Biecek, P. (2017). "intsvy: An R Package for Analyzing International Large-Scale Assessment Data." Journal of Statistical Software_, ${ }^{\star} 81^{\star}(7), 1-44$. doi: $10.18637 /$ jss.v081. i07

Cortina, K.S. (2015). PIAAC and PISA. Pädagogisch paradoxe Parallelen [Pedagogically paradoxical parallels] [in German]. Zeitschrift für Pädagogik, 61, 223-242

Educational expenditure statistics. (2019). Retrieved 22/04/2020, from https://ec.europa. eu/eurostat/statistics-explained/index.php?title=Educational_expenditure_statistics\#Public_expenditure

Feinberg, I., Tighe, E.L., Talwar, A., and Greenberg, D. (2019). Writing Behaviors Relation 
to Literacy and Problem Solving in Technology-Rich Environments: Results from the 2012 and 2014 U.S. PIAAC Study

Goldhaber, D.D., \& Brewer, D.J. (2000). Does Teacher Certification Matter? High School Teacher Certification Status and Student Achievement. Educational Evaluation and Policy Analysis, 22(2), 129-145. Retrieved 7/09/2021, from https://doi. org/10.3102/01623737022002129

Hanushek, E.A., \& Rivkin, S.G. (2006). Teacher quality. Handbook of the Economics of Education, 2, 1051-1078

Hanushek, E.A., Piopiunik, M., \& Wiederhold, S. (2014). The value of smarter teachers: international evidence on teacher cognitive skills and student performance. NBER Working Paper No. 20727

Ibrahim, A. \& Zataari, W.E. (2019): The teacher-student relationship and adolescents' sense of school belonging, International Journal of Adolescence and Youth, DOI:10.1080/02 673843.2019.1660998

Li-Xu \& Qi Yang (2019). Modelling and Analysis on Teacher- Student Relationship. Retrieved 25/04/2020, from https://www.researchgate.net/publication/338231812_ Modeling_and_Analysis_on_Teacher-Student_Relationship

Lundetræ, K., Sulkunen, S., \& Gabrielsen, E. (2014). A comparison of PIAAC and PISA results. In A. Malin (Ed.), Associations between age and cognitive foundation skills in the Nordic countries (pp. 171-187). Jyväskylä, Finland: The Finnish Institute for Educational Research

Meroni, E.C., Vera-Toscano, E., \& Costa, P. (2015). Can low skill teachers make good students? Empirical evidence from PIAAC and PISA. Journal of Policy Modeling, 37(2), 308-323. Retrieved 12/06/2020, from https://doi.org/10.1016/j.jpolmod.2015.02.006

Metzler, J. \& Woessmann, L. (2012). The impact of teacher subject knowledge on student achievement: Evidence from within-teacher within-student variation. Journal of Development Economics, 99(2), 486-496

OECD (2012). Literacy, Numeracy and Problem Solving in Technology-Rich Environments:

Framework for the OECD Survey of Adult Skills, OECD Publishing. Retrieved 7/06/2020, from http://dx.doi.org/10.1787/9789264128859-en

OECD (2013). OECD skills outlook 2013: First results from the survey of adult skills. Retrieved 17/08/2021, from http://dx.doi.org/10.1787/9789264204256-en

OECD (2016). Technical report of the Survey of Adult Skills (PIAAC) (2 ${ }^{\text {nd }}$ edition). Retrieved 17/06/2020, from http://hdl.voced.edu.au/10707/423821

R Core Team (2018). R: A language and environment for statistical computing. R Foundation for Statistical Computing, Vienna, Austria. Retrieved 22/04/2020, from https:// www.R-project.org/

Rice, J.K. (2003). Teacher Quality: Understanding the Effectiveness of Teacher Attributes. Economic policy Institute, Washington, DC.

Uhrínová, M., \& Tirpák, J. (2020). Teacher's Personality With Regard to Performance 
Motivation in a Professional Context. The New Educational Review, 47-58. Retrieved 4/06/2020, from https://doi.org/10.15804/tner.2020.59.1.04

von Davier, M., Weeks, J., Chen, H., Allen, J., \& van der Velden, R. (2016). Creating simple and complex derived variables and validation of background questionnaire data. In Survey of Adult Skills Technical Report, Second Edition (pp. 20-1-20-22). Retrieved 7/06/2020, from http://www.oecd.org/skills/piaac/publications.htm

Vzdelávanie a zručnosti Online [Education and Skills Online] (PIAAC Online) (2020). www.Nucem.Sk. Retrieved 7/07/2020, from https://www.nucem.sk/sk/merania/medzinarodne-merania/piaac/piaac-online

Yamin, M. (2018). Enhancing Teachers' Literacy Competence Through Critical Writing in The Digital Era: International Journal of Pedagogy and Teacher Education (IJPTE), 2(2), 401-412. Retrieved 17/5/2020, from https://www.researchgate.net/publication/329551318_Enhancing_Teachers'_Literacy_Competence_through_Critical_Writing_in_Digital_Era

Základná informácia o výsledkoch štúdie OECD TALIS 2013 (n.d.) [Basic Information about results of the OECD study TALIS 2013 (n.d.)] Retrieved 7/06/2020, from https:// www.minedu.sk/data/att/6463.pdf 